\title{
POSSIBILITY OF UTILIZING THE PREDATORY MITE, NEOSEIULUS CALIFORNICUS (MCGREGOR) (ACARI: PHYTOSEIIDAE) FOR CONTROLLING TWO ERIOPHYOID FIG MITES, ACERIA FICUS (COTTE) AND RHYNCAPHYTOPTUS FICIFOLIAE KEIFER (ACARI: ERIOPHYIDEA)
}

\author{
A.M. Halawa \\ Fruit Acarology Department, Plant Protection Research Institute (PPRI), Agricultural Research \\ Center (ARC), Egypt \\ E-Mail: eriomite@yahoo.com , dr.alaahalawa@gmail.com
}

Received: Apr. 13, 2017

Accepted: Apr. 22,2017

\begin{abstract}
The life history and predation rate of the predatory mite, Neoseiulus californicus (McGregor) on fig bud mite, Aceria ficus (Cotte) and fig leaf mite, Rhyncaphytoptus ficifoliae Keifer, were studied separately at $25^{\circ} \mathrm{C}$ and $60-70 \%$ R.H. The predatory mite completed its life span when fed on the mentioned mites. The predation rate, life cycle, and oviposition periods varied depending on type of prey. The development was quickest and number of prey consumed was highest when individuals were maintained on $A$. ficus, compared with $R$. ficifoliae. The sex ratio (female: male) was slightly lower on $A$. ficus as prey than on $R$. ficifoliae where it was 2.0:1 and 2.1:0.9, respectively. The average number of eggs/female/day was 2.98 and 1.67 with total average 37.2 and $23.2 \mathrm{egg}$ on fig bud and fig leaf mites, respectively. The total average of prey consumed by predatory mite were 265.7 \& 239.3 and 236.4 \& 211 individual for female and male when fed movable stages of $A$. ficus and $R$. ficifoliae, respectively.
\end{abstract}

Key words: Neoseiulus californicus, Development, Life span, Predation, Aceria ficus, Rhyncaphytoptus ficifoliae.

\section{INTRODUCTION}

The fig is one of the oldest deciduous fruit that attacked by many pests. In Egypt, three injurious mites were commonly found on the fig trees: fig bud mite Aceria ficus (Cotte), fig leaf mite Rhyncaphytoptus ficifoliae Keifer, and the two-spotted spider mite Tetranychus urticae Koch. The most familiar symptoms caused by these mites are rusting or surface browning, bud blasting, impedance of new growth, bud distortion and leaf chlorosis. Severe infestation may result in defoliation of branches or whole trees (Abd-Elkhalek, 1993; Abou-Awad et al., 1999). In addition, The eriophyid mite $A$. ficus is one of the most important and injurious species in the family Eriophyidae, because it is not only damages fig trees by feeding but it is also a vector of fig mosaic virus disease (AbouAwad et al 1999; Halawa,2003). The long- term use of certain pesticides in chemical programs in Egypt may be partially responsible for the increase of injurious mite numbers on cultivated crops. These adverse changes can be minimized by delaying application to allow native bio-control agents to have an affect (Abou-Awad et al 1999). The predacious mites from family Phytoseiidae Berlese and Stigmaeidae Oudemans are documented for controlling eriophyoid and tetranychid mites by several authors (Zaher \& Elbadry, 1961; Schuster \& Pritchard, 1963; McMurtry et al., 1970; Solomon, 1975; Rice et al., 1976; Yousef et al., 1982; Abou- Awad, 1983; El-Bagoury \& Reda, 1985; Kroperynska \& Tuovinen, 1988; Amano \& Chant, 1990; Abou-Awad \& ElSawi, 1993). Accordingly, the predacious mite, Neoseiulus californicus (McGregor) appears to act as a generalist predator against tetranychid mites and can initiate 
multiple attacking behaviors. On the other hand, the behavior of $N$. californicus suggests that, it is opportunistic and capable of capturing several different types of prey (Takano-Lee and Hoddle, 2002). It feeds successfully on species of eriophyid mites as it quickly accepts Oxycenus niloticus (Zaher and Abou-Awad) and Aculops lycopersici (Massee) as preys. ( Ebrahim et al, 2013). The current study aims to investigate the possibility of Neoseiulus californicus to complete its life- span when fed on individuals of the fig bud mite, $A$. ficus, and fig leaf mite, $R$. ficifoliae.

\section{MATERIALS AND METHODS}

Life history characteristics and predation of $N$. californicus on the eriophyid mites $A$. ficus and $R$. ficifoliae were conducted in the laboratory at $25{ }^{\circ} \mathrm{C}$ and $70 \pm 5 \% \mathrm{R}$.H. The eriophyid mites were collected from the lower surface of ficus leaves Ficus carica $\mathrm{L}$. Petri dishes as rearing units were coated on its lower surface with a layer of moist cotton wool and put in big Petri dishes full with water to provide moisture continuously. Five small pieces discs of ficus leaves (about 2.5 $\mathrm{cm}$ diameter), were put upside down on the moist cotton. A layer of wet cotton was placed around each leaf disc as barrier to confine the predator to a definite area. One egg of $N$. californicus was put on each disc for development to the moving stage and was observed twice daily. When the $N$. californicus larvae hatched, a small piece of ficus leaves with counted number of $A$. ficus and $R$. ficifoliae were placed on each disc assigned for $A$. ficus or $R$. ficifoliae. Thus, one $N$. californicus larva was liberated on each disc, and the numbers of prey eaten during its larval, protonymphal, deutonymphal and adult female or male were recorded. Surplus food was provided whenever the supply became low or the ficus leaves need to change. The fecundity of $N$. californicus was determined at $25^{\circ} \mathrm{C}$. Before the final molt of the female deutonymph, one adult male was provided and was ensured to mate once. The male was then removed and observations were made at intervals twice a day until the first egg was laid. Thereafter, the number of laid eggs was recorded every 24 hours until the ovipositing female died. All resulting hatched larvae were transferred to new excised ficus leaves and reared until adult stage to record the sex ratio of resultant progeny. Oviposition, pre-and post-oviposition periods were also recorded.

Statistical analysis: One way ANOVA was calculated by using SPSS program. In addition, LSD (Fisher's Significant Difference Test) was chosen to identify the significant difference.

\section{RESULTS}

The predatory mite $N$. californicus was succeed to complete its life cycle on two different species of eriophyid mites at similar condition $25{ }^{\circ} \mathrm{C}$ and $70 \pm 5 \%$ R.H. The developmental time for male and female of $N$. californicus reared on two eriophyid mites (A. ficus or $R$. ficifoliae) are recorded in Table (1). The adult females of predacious mite were needed 12.22 day to develop from egg to adult when fed $A$. ficus while, it required 13.1 day to develop from egg to adult when fed on $R$. ficifoliae with significant difference (0.257). Under similar conditions, the duration of different stages of $N$. californicus were affected by type of prey where the incubation period; larval stage ,protonymph; deutonymph of female were required shortest time when fed on $A$. ficus $(4.35 ; 2.38 ; 2.55 ; 2.94$ day, respectively with total immature time 7.87 day) while the duration of egg; larva; protonymph; deutonymph required $(4.35 ; 275 ; 2.97 ; 303$ day, respectively with total immature time 8.75) when fed on $R$. ficifoliae Table (1). Significant difference (0.1913) was found between total immature time for females of $N$. californicus when fed on $A$. ficus and $R$. ficifoliae. Similar trend was recorded on the duration of life cycle for males of $N$. californicus (11.69 and 12.67 day) when fed on movable stages of $A$. ficus and $R$. ficifoliae with high significant difference 
(0.3367). The different stages of life cycle ( egg, larva, protonymph, deutonymph) for males were required shorter time (4.05; 2.22; $2.48 ; 2.93$ day, respectively, with total immature 7.64 day) when fed on $A$. ficus than $R$. ficifoliae where the different stages of life cycle required $(4.1 ; 2.73 ; 2.94 ; 2.95$ day, respectively with total immature 8.62 day), therefore highly significant difference $(0.3165)$ was found between the duration of life cycle for males of $N$. californicus depending on type of prey. The generation time also was affected by type of prey where it was 13.65 day and 14.79 day when fed on $A$. ficus and $R$. ficifoliae, respectively ,Table (2).

Table (1): Average duration of the immature stages of $N$. californicus when fed on eriophyoid mites $A$. ficus and $R$. ficifoliae at $25 \pm 2 \circ \mathrm{C}$ and $70 \pm 5 \%$ R.H.

\begin{tabular}{|l|c|c|c|c|}
\hline \multirow{2}{*}{ Developmental stages } & \multicolumn{2}{|c|}{$\begin{array}{c}\text { A. ficus } \\
\text { Mean } \pm \text { S.D }\end{array}$} & \multicolumn{2}{c|}{$\begin{array}{c}\text { R. ficifoliae } \\
\text { Mean } \pm \text { S.D }\end{array}$} \\
\cline { 2 - 5 } & Female & Male & Female & Male \\
\hline Incubation period & $4.35 \pm 0.24^{\mathrm{a}}$ & $4.05 \pm 0.12^{\mathrm{b}}$ & $4.35 \pm 0.24^{\mathrm{a}}$ & $4.1 \pm 0.12^{\mathrm{b}}$ \\
\hline Larva & $2.38 \pm 0.10^{\mathrm{a}}$ & $2.22 \pm 0.09^{\mathrm{c}}$ & $2.75 \pm 0.10^{\mathrm{b}}$ & $2.73 \pm 0.12^{\mathrm{d}}$ \\
\hline Protonymph & $2.55 \pm 0.10^{\mathrm{a}}$ & $2.48 \pm 0.02^{\mathrm{c}}$ & $2.97 \pm 0.09^{\mathrm{b}}$ & $2.94 \pm 0.008^{\mathrm{d}}$ \\
\hline Deutonymph & $2.94 \pm 0.10^{\mathrm{a}}$ & $2.93 \pm 0.02^{\mathrm{c}}$ & $3.03 \pm 0.11^{\mathrm{a}}$ & $2.95 \pm 0.03^{\mathrm{c}}$ \\
\hline Total immature & $7.87 \pm 0.20^{\mathrm{a}}$ & $7.64 \pm 0.08^{\mathrm{c}}$ & $8.75 \pm 0.20^{\mathrm{b}}$ & $8.62 \pm 0.03^{\mathrm{d}}$ \\
\hline Life cycle & $12.22 \pm 0.29^{\mathrm{a}}$ & $11.69 \pm 0.15^{\mathrm{c}}$ & $13.1 \pm 0.24^{\mathrm{b}}$ & $12.67 \pm 0.12^{\mathrm{d}}$ \\
\hline
\end{tabular}

Different letters ( $a$ and $b$ between females while $c$ and $d$ for males) in horizontal column denote significant difference .

Table (2): Average duration of various adult periods, generation, of $\boldsymbol{N}$. californicus and number of eggs laid by the adult females when fed on eriophyoid mites $A$. ficus and $R$. ficifoliae at $25 \pm 2^{\circ} \mathrm{C}$ and $70 \pm 5 \%$ R.H.

\begin{tabular}{|l|c|c|c|c|}
\hline \multirow{2}{*}{ Predator stage } & \multicolumn{2}{|c|}{$\begin{array}{c}\text { A. ficus } \\
\text { Mean } \pm \text { S.D }\end{array}$} & \multicolumn{2}{c|}{$\begin{array}{c}\text { Mean ficifoliae } \\
\end{array}$} \\
\cline { 2 - 5 } & Female & Male & Female & Male \\
\hline Pre-oviposition & $1.43 \pm 0.08^{\mathrm{a}}$ & - & $1.69 \pm 0.09^{\mathrm{b}}$ & - \\
\hline Generation & $13.65 \pm 0.29^{\mathrm{a}}$ & - & $14.79 \pm 0.20^{\mathrm{b}}$ & - \\
\hline Oviposition & $12.44 \pm 0.17^{\mathrm{a}}$ & - & $13.85 \pm 0.18^{\mathrm{b}}$ & - \\
\hline Post-oviposition & $7.07 \pm 0.16^{\mathrm{a}}$ & - & $6.21 \pm 0.21^{\mathrm{b}}$ & - \\
\hline Adult longevity & $20.94 \pm 0.24^{\mathrm{a}}$ & $19.8 \pm 0.18^{\mathrm{c}}$ & $21.75 \pm 0.16^{\mathrm{b}}$ & $17.22 \pm 0.34^{\mathrm{d}}$ \\
\hline Life span & $33.16 \pm 0.40^{\mathrm{a}}$ & $31.4 \pm 0.4^{\mathrm{c}}$ & $34.86 \pm 0.31^{\mathrm{b}}$ & $29.8 \pm 0.40^{\mathrm{d}}$ \\
\hline No. of eggs/female & $37.2 \pm 1.26^{\mathrm{a}}$ & - & $23.3 \pm 1.94^{\mathrm{b}}$ & \\
\hline No. of eggs/female/day & $2.98 \pm 0.14^{\mathrm{a}}$ & - & $1.67 \pm 0.13^{\mathrm{b}}$ & - \\
\hline Sex ratio (female: male) & $2.3: 0.7$ & - & $2.1: 0.9$ & - \\
\hline
\end{tabular}

Different letters ( $a$ and $b$ between females while $c$ and $d$ for males) in horizontal column denote significant difference . 
The average duration of longevity for females and males were recorded in Table (2) where they were $20.94 \& 21.75$ day and 19.8 \& 17.22 day for females and males when fed on $A$. ficus and $R$. ficifoliae, respectively. The ovipostion period was the longest (13.85 day) when the predator mite $N$. californicus fed on $R$. ficifoliae, while it was 12.44 day when fed on $A$. ficus. The adult female was lived after stopped laying egg for 7.07 and 6.21 day when fed on $A$. ficus and $R$. ficifoliae, respectively. Therefore, the time of life span was affected by type of prey where it was $33.16 \& 34.86$ day for females and 31.4 \&29.8 day for males when fed on A. ficus and R. ficifoliae, respectively. In addition, significant differences were found between females (0.3364) and between males (0.5162) depending on type of prey. Female oviposited 37.2 and 23.3 eggs, with a daily rate of 2.98 and 1.67 eggs on the $A$. ficus and $R$. ficifoliae, respectively. Significant difference $(0.1383)$ was found between the two prey species. However, the sex ratio (female : male) was slightly lower on $A$. ficus as prey than on $R$. ficifoliae where it was 2.0:1 and 2.1:0.9, respectively.

\section{Food consumption:}

Data in Table (3) shows the numbers of both eriophyoid prey consumed by different stages of predacious mite. The larval stage of female was consumed 3.5 individual from each prey $A$. ficus and $R$. ficifoliae while, the larval stage of male was consumed 2.75 and 2.4 individual of $A$. ficus and $R$. ficifoliae, respectively. In addition, the protonymphal stage of female was devoured 18.8 \& 16.5 individual of $A$. ficus and $R$. ficifoliae, respectively while, the protonymphal stage of males was devoured 16.5 individuals from each prey. The consumption rate was increased in deutonymphal stage for males and females where the total average of consumption were 25.1 \&24.3 individuals and 22.5\& 20.4 individuals for females and males from $A$. ficus and $R$. ficifoliae, respectively. The females through ovipostion period were very active of feeding where a total average of consumed prey were 142.4 and 125.2 individuals of $A$. ficus and $R$. ficifoliae, respectively. Moreover, the consumption rate for adult female was decreased after stopped of egg laying, where the total average of consumed prey was $60.3 \& 52.8$ individuals of $A$. ficus and $R$. ficifoliae, respectively. On the other hand, the adult males were less than females in food consumption, the consumption rates of males of predator mite $N$. californicus were 179.5 \& and 172 individuals while the consumption rates of females were 218.3 \& 191.6 individuals of $A$. ficus and $R$. ficifoliae, respectively. Females consumed 265.7 individual of $A$. ficus and 236.4 individual of $R$. ficifoliae during life span while males consumed 239.3 individual of $A$. ficus and 211 individual of $R$. ficifoliae .Thus, the mentioned data showing a preference for the fig bud mite $A$. ficus with .

\section{DISCUSSION AND CONCLUSION}

Like many phytoseiids, $N$. californicus has a wide range of host preys i.e. tetranychoids, eriophyids, insects and pollen grains (Swirski et al., 1967; Metwally et al., 1984; El-laithy \& Fouly, 1992; Momen \& ElSawi, 1993; Abou-Awad et al, 1999). In the present study, $N$. californicus developed successfully from larva to adult when fed on eriophyoid fig mites $A$. ficus and $R$. ficifoliae. Development was faster and reproduction was higher when fed on $A$. ficus. Development was more rapid for males than for females, this might be advantageous for successful mating (Amano \& Chant, 1977). Adults were able to mate immediately after the final moult. The rapid development of predacious mites has commonly been accepted by Acarologists as being advantageous for the control of pest mites in the field. At the same time, the superiority of prey species as food for the most phytoseiid mites has also been judged by the short developmental times of the phytoseiid feeding on them (Amano \& Chant, 1986, 
Abou-Awad et al, 1999), as mentioned that, the larval stages of the predatory mite, Amblyseius swirskii Athias-Henriot did not feed on eriophyid prey while this study agree with Schausberger \& Croft, (2014) they mentioned that, the larvae of $N$. fallacis (Garman), N. californicus, and Amblyseius andersoni Chant are facultative feeders. However, Abou-Awad (1983) mentioned above reported that the larval feeding in phytoseiids depends on the species studied. Many published literature reveals some different data under similar conditions, Ebrahim et al (2013) recorded that the adult females of $N$. californicus lived an average of 12.08 and 29.76 day and laid only 1.73 , and 1. 86 eggs/day when fed on eriophyid mite Oxycenus niloticus Zaher and AbouAwad and Tetranychus urticae Koch respectively. In this study, females lived for 20.94 and 21.75 days, while ovipositing 2.98 and 1.67 eggs/day when fed on the fig bud and fig leaf mites, $A$. ficus and $R$. ficifoliae, respectively. The fecundity of predacious mite $N$. californicus when fed on fig bud mite, $A$. ficus was higher than previously recorded on tetranychoids and eriophyids.
Other studies showed several phytoseiid mites to be major predators of eriophyids: $N$. californicus, Amblyseius fallacies Garmen, Typhlodromus rickeri Chant, Phytoseius finitimus Ribaga, Amblyseius olivi Nasr \& Abou-Awad, Amblyseius finlandicus (Oudemans) and $A$. andersoni (McMurtry \& Scriven, 1964; EL-Banhawy, 1974, AbouAwad \& EL-Banhawy, 1986; Duso \& Camporese, 1991).The females and males of the predatory mites, $N$. californicus consumed an average total of $218.3,197.5$ $A$. ficus or $191.6,172.0 R$. ficifoliae during the adult stage. The current study showing a preference for the fig bud mite, $A$. ficus . Abou- Awad et al.(1999) and Sabelis (1981) reported that the prey consumption consisted of a ratio of about $70 \%$ of the biomass of deposited eggs. The total eggs deposited during oviposition period represented about $70 \%$ from total protein of prey. Finally, The present result as other previous studies indicated that $N$. californicus can play a good role in the control of eriophyid fig mites, $A$. ficus and $R$. ficifoliae.

Table (3): Number of prey consumed by different postembryonic stages of $N$. californicus fed on eriophyoid mites $A$. ficus and $R$. ficifoliae at $25 \pm 2{ }^{\circ} \mathrm{C}$ and70 $\pm 5 \%$ R.H.

\begin{tabular}{|c|c|c|c|c|}
\hline \multirow{2}{*}{ Predator stages } & \multicolumn{2}{|c|}{$\begin{array}{c}\text { A. ficus } \\
\text { Mean } \pm \text { S.D }\end{array}$} & \multicolumn{2}{|c|}{$\begin{array}{l}\text { R. ficifoliae } \\
\text { Mean } \pm \text { S.D }\end{array}$} \\
\hline & Female & Male & Female & Male \\
\hline Larva & $3.5 \pm 0.70^{a}$ & $2.75 \pm 0.5^{c}$ & $3.5 \pm 0.7^{a}$ & $2.4 \pm 0.5^{d}$ \\
\hline Protonymph & $18.8 \pm 1.3^{a}$ & $16.5 \pm 0.6^{c}$ & $16.5 \pm 1.0^{b}$ & 16. $5 \pm 0.5^{c}$ \\
\hline Deutonymph & $25.1 \pm 0.8^{a}$ & $22.5 \pm 0.6^{c}$ & $24.30 \pm 1.1^{\mathrm{a}}$ & $20.4 \pm 1.5^{d}$ \\
\hline Total immature & $47.4 \pm 2.0^{\mathrm{a}}$ & $41.8 \pm 0.5^{c}$ & $44.80 \pm 1.9^{b}$ & $39.4 \pm 1.8^{d}$ \\
\hline Pre-oviposition & $15.4 \pm 1.2^{b}$ & - & $13.6 \pm 0.52^{a}$ & \\
\hline Oviposition & $142.6 \pm 2.3^{a}$ & - & $125.2 \pm 2.3^{b}$ & \\
\hline Post-oviposition & $60.3 \pm 1.95^{a}$ & - & $52.8 \pm 2.4^{b}$ & \\
\hline Adult longevity & $218.3 \pm 3.78^{a}$ & $197.5 \pm 2.4^{c}$ & $191.6 \pm 3.2^{b}$ & $172 \pm 2.9^{d}$ \\
\hline Life span & $265.7 \pm 6.7^{\mathrm{a}}$ & $239.3 \pm 2.1^{c}$ & $236.4 \pm 5.1^{b}$ & $211 \pm 4.0^{d}$ \\
\hline
\end{tabular}

Different letters ( $a$ and $b$ between mean total of prey consumed by females while $c$ and $d$ for mean total of prey consumed by males) in horizontal column denote significant difference . 


\section{REFERENCES}

Abdel-Khalek , A. A. (1993). Studies on mites associated with fig trees in Qaliubia governorate. M.Sc. Thesis, Fac. Science, Ain Shams Univ., 143 pp.

Abou-Awad, B. A. (1983). Amblyseius gossipi (Acarina: Phytoseiidae) as a predator of the tomato eriophyoid mite, Eriophyes lycopersici (Acarina: Eriophyidae). Entomophaga, 28: 363366

Abou-Awad, B. A. and E. M. El-Banhawy (1986). Biological studies of Amblyseius olivi, a new predator of eriophyid mites infesting olive trees in Egypt (Acari: Phytoseiidae).Entomophaga, 31: 99103.

Abou-Awad, B. A. and S. A. El-Sawii (1993). Biology and life table of the predacious mite, Agistemus exsertus Gonz. (Acari: Stigmaeidae). Anz. Schadl. Pfianz. Umwelt., 66: 101-103.

Abou-Awad, A.B., B.M. El-Sawaf and Amira A. Abdel-Khalek (1999). Impact of two eriophyoid fig mites , Aceria ficus and Rhyncaphytoptus ficifoliae, as prey on post embryonic development and oviposition rate of the predacious mite, Amblyseius swirskii. Acarologia, 40 : 419-429.

Amano, H. and D. A. Chant (1977). Life history and reproduction of two species of predacious mites, Phytoseiulus persimilis Athias-Henriot and Amblyseius andersoni (Chant) (Acarina: Phytoseiidae). Can. J. Zool., 55: 1978-1983.

Amano, H. and D. A. Chant (1986). Laboratory studies on the feeding habits, reproduction and development of three phytoseiid species, Typhlodromus pomi, Phytoseius macropilis and Amblyseius jinlandicus (Acari: Phytoseiidae), occurring on abandoned apple trees in Ontario,
Canada. Exp. Appl. Acarol., 2: 299313.

Amano, H. and D. A. Chant (1990). Species diversity and seasonal dynamics of Acari on abandoned apple trees in Southern Ontario, Canada. Exp. Appl. Acarol., 8: 71-96.

Duso, C. and P. Camporese (1991). Developmental times and oviposition rates of the predatory mites Typhlodromus pyri and Amblyseius andersoni (Acari: Phytoseiidae) reared in different foods. Exp. Appl. Acarol., 13: 117128.

Ebrahim, A.A., A.A.M. Abdallah and K. M. Elsayed (2013). Possibility of Utilizing Neoseiulus californicus (Mcgregor) (Acari: Phytoseiidae) to Control Oxycenus niloticus Zaher and AbouAwad (Acari: Eriophyidae). Acarines, 7 (2); 63-66.

El-Bagoury, M. E. and A. S. Reda (1985). Agistemus exsertus Gonzalez (Acarina: Stigmaeidae) as a predator of the Ploughman's spikenard gall mite, Eriophyes dioscoridis (Eriophyidae). Bull. Fac. Agric. Univ. Cairo, 36: 571567.

El-Banhawy, E. M. (1974). Life history studies on the predatory mite Phytoseius jinitimus Ribaga (Acarina: Phytoseiidae). Rev. Bras. Biol., 34: 437-442.

El-Laithy, A. Y. M. and A. H. Fouly (1992). Life table parameters of the two phytoseiid predators Amblyseius scutalis (Athias-Henriot) and A. swirskii A.-H. (Acari: Phytoseiidae) in Egypt. Appl. Ent., 113: 8-12.

Halawa, A.M. (2003). Studies on some mites and their relationship with virul diseases. Ph.D. Thesis, Fac. Agric., Benha Univ., 206 pp.

Kroperynska, D. and T. Touvinen (1988). Occurrence of phytoseiid mites (Acari: Phytoseiidae) on apple trees in Finland. Ann. Agric. Fenniae, 27: 305-314. 
McMurtry, J. A. and G. T. Scriven (1964). Studies on feeding, reproduction and development of Amblyseius hibisci (Acarina: Phytoseiidae) on various food substances. Ann. Entomol. Soc. Am., 57: 649-655.

McMurtry, J. A., C. B. Huffaker and D.E. Van (1970). Ecology of tetranychid mites and their natural enemies: A review I. Tetranychid enemies: Their biological characters and the impact of spray practices. Hilgardia, 40: 331-390.

Metwally, A. M., M. M. Abou-Elnaga, H. A. Taha and F. M. Hoda (1984). Studies on feeding reproduction and development of Amblyseius swirskii A.$\mathrm{H}$. (Acarina: Phytoseiidae). Agric. Res. Rev., 62: 323-236.

Momen, F. M. and S. A. El-Sawi (1993). Biology and feeding behaviour of the predatory mite, Amblyseius swirskii (Acarina: Phytoseiidae). Acarologia, 34: 199204.

Rice, R. E., R. A. Ones and M. L. Hoffmann (1976). Seasonal fluctuations in phytophagous and predacious mite populations on stone fruits in California. Environ. Entomol., 5: 557-564.

Sabelis, M. W. (1981). Biological control of two-spotted spider mites using phytoseiid predators. Part I: Modeling the predator-prey interaction at the individual level. Pudoc., Wageningen, Agric. Res. Rep. 910: 242 pp.

Schuster, R. 0 and A. E. Pritchard (1963). Phytoseiid mites of California. Hilgardia, 34: 191-285.
Solomon, M. G. (1975). The colonization of an apple orchard by predators of the fruit tree red spider mite. Ann. Appl. Biol., 80: 119-122.

Schausberger, P. and B.A. Croft (2014). Activity, Feeding, and development among larvae of specialist and generalist phytoseiid mite species (Acari: Phytoseiidae). Environ Entomol. 28 (2): 322-329.

Swirski, E., S. Amitai and N. Dorzia (1967). Laboratory studies on the feeding, development and reproduction of the predacious mites Amblyseius rubini Swirski and Amitai and Amblyseius swirskii Athias-Henriot (Acarina: Phytoseiidae) on various kinds of food substances. Israel. Agric. Res., 17: 101-119.

Takano-Lee, M. and M. Hoddle (2002). Predatory behaviors of Neoseiulus californicus and Galendromus helveolus (Acari: Phytoseiidae) attacking Oligonychus perseae (Acari: Tetranychidae). Exp. Appl. Acarol., 26: 13-26.

Yousef, A. A., M. A. Zaher and A. M. AbdelHafez (1982). Effect of prey on the biology of Amblyseius gossipi El-Badry and Agistemus exsertus Gonzalez (Acarina: Phytoseiidae, Stigmaeidae). Z. Ang. Ent., 93: 453-456.

Zaher, M. A. and E. A. El-Badry (1961). Life history of the predator mite, Agistemus fleschneri Summers, and effect of nutrition on its biology. Bull. Soc. Ent. Egypt, 45: 375-385. 
Neoseiulus californicus (McGregor) إمكانية إستخدام المفترس الاكاروسى لمكافحة حلم براعم وأولق التين الدودى (Acari: Phytoseiidae) Aceria ficus (Cotte) \& Rhyncaphytoptus ficifoliae Keifer (Acari:

\section{Eriophyoidea)}

\section{علاء محمد حلاوه}

قسم بحوث اكاروس الفاكهة - معهد بحوث وقاية النباتات - مركز البحوث الزراعية الملخص العربى

Neoseiulus californicus (McGregor) تمت دراسة تاريخ الحياة ومعدل الافتراس للمفترسى الاكاروسى

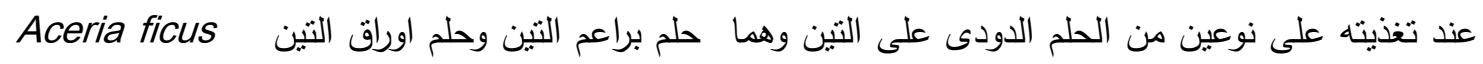
(Cotte), Rhyncaphytoptus ficifoliae Keifer نسبية 70 ن اثتتت الدراسة نجاح المفترس فى استكمال دورة حياته عند تغذيته على الاكاروسات المذكورة كما اثتتت الدراسة

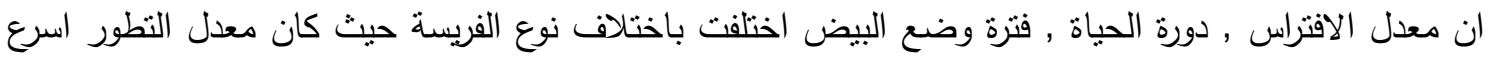
ومعدل الافتراس اعلى عند تغذية المفترس على اكاروس براعم التني Aceria ficus حيث منوسط معدل الافتراس 265,7 \& 239,3 و 236,4 \& 211 فرد للاناث والذكور عند تغذيته على اكاروس براعم التين واكاروس اوراق التين على التوالى بينما كان المعدل اليومى للانتى فى وضع البيض 2,98 و 1,67 بمتوسط كلى 237 237 و 23,2 بيضة عند تغذية اكاروس براعم التين واكاروس اوراق التين على التوالى . 
Menoufia J. Plant Prot., Vol. 2 June (2017): 223 - 230 